\title{
Coercive Conduct and Rationalization of Religion Lead to Dilution of Faith in Bless Me, Ultima by Rudolfo A. Anaya
}

\section{A. Minderop}

Department of English, Faculty of Letters, University of Darma Persada, Jalan Radin Inten II, East Jakarta 13450, Indonesia

\section{Abstract}

The aim of this research is to show that coercive conduct and rationalization of religion lead to a dilution of faith. The method used in this research is content analysis and the technique of hermeneutics. Content analysis is used to explore the ideas expressed by the author in the form of statements, questions, and dialogs of the characters. This method aims to uncover, understand, and grasp the message of literary works. The

Corresponding Author:

A. Minderop

aminderop@yahoo.com

Received: 6 April 2018

Accepted: 3 May 2018

Published: 26 July 2018

Publishing services provided by Knowledge $\mathrm{E}$

(c) A. Minderop. This article is distributed under the terms of the Creative Commons

Attribution License, which

permits unrestricted use and redistribution provided that the original author and source are credited.

Selection and Peer-review under the responsibility of the ISLLE 2017 Conference Committee. method of interpretation used in this research involves the techniques of hermeneutics (theory of interpretation). Hermeneutics is the best strategy for interpreting the texts of philosophy and literature. The study was designed to facilitate the interpretation of deep understanding figurative language so that the researcher is able to reach the deepest meaning of literature because the researcher has a complete knowledge of the culture, religion, and history, not just knowledge of the language, literature, and aesthetics. The result of the research is the coercive conduct in defense of religion (covered: the compulsion to read the prayer, defense of faith by force, bizarre and frightening sermons) and rationalization of religion. The discussion of the research is that coercive conduct and rationalization of religion lead to dilution of faith.

Keywords: coercion, dilution, faith, rationalization, religion

\section{Introduction}

Bless Me, Ultima tells the readers about difficult figures relating to children. First, there was coercion of parents in carrying out religious activities, making them bored and tired. Second, there were miserable incidents that were experienced by the children. They considered that their experience was not in accordance with the teachings of God that they learned from their parents. Third, the sermons of religious leaders were 
from other children for the sake of defending the religion. The main character in this novel is six-year-old Antonio (Tony) and some other child figures.

According to Herrera [1] in the course of the novel, throughout three years of spiritual genesis, the boy (Antonio) is torn between maternal forces: the earth, Catholic ritual, family ties; and the opposing power: the flowing river, the golden carp (its god), the dream of nomadic liberation. His mother would have him be a priest. She is a luna, a descendant of the Spanish priest who settled the farming valley. But Antonio has the blood of the Marez, of the changing and inconstant sea. His father's primitive roots are Antonio's connection to older myths; he cannot embrace the Catholic faith without struggle and ambivalence [1]. His mother wants him to become a priest [2].

According to Testa [3] the elements of reality and the elements of his fantasy world, legends, stories, etc., appear obsessively and dynamically charged and join to make new combinations that surprise, frighten, and shock. The visionary mode, with its confusions, chaos, and conflicts, leaves us with a sense of fear and mystery about life and the cosmos. At any rate, we should note the contrast between the unrestrained flow of the dreams and the other parts of the book, between the condensation and obsessiveness of certain horrific patterns and the stability and relative security of Antonio's 'real' world. Testa [3] continued that in Anaya's novel there is a thematic dimension that runs throughout the whole work. What slowly emerges from the work is a view of the world in which evil plays a strong and constantly threatening role in the lives of people [3].

Religious teachings that Tony got from his mother always taught kindness and peace, but the reality he experienced daily was away from those values. Since the teachings of religion were the opposite of everyday events, Tony and his friends doubted their religious beliefs. We recall that the novel is basically an account of Antonio's psychological, vocational, religious or philosophical, and cultural struggle [3]. Their belief worsened when the pastor gave the sermon that was very scary and unreasonable. All of these incidents and experience made the children confused. They asked why God punished people who were innocent and why some friends defended religion by having to fight and attack them mercilessly. God is almighty, isn't He? Why should God be defended by force? To answer all these questions, the children began to discuss the existence of God and religion rationally based on the logic of children. They did not find a satisfactory answer, but they tried to find a solution on their own. Some of the children became reluctant to follow the worship and others were enveloped with confusion. This contradictory belief led to disagreements and quarrels. They were 
finally involved in physical conflicts with the defenders of the religion. Florence, one of Tony's friends, was often blasphemous and neglected by his friends.

Although the action will involve other characters, the primary conflict will be the struggle for possession of the boy narrator's soul and his destiny. It is a battle for control of his imagination. The "blessing" asked for in the title of the novel is really that singular benediction we all seek-the one which will give us surcease from endless attachment and disillusion with the successive vision of how things are-or, more succinctly, the blessing called faith [2].

The problem of the research is why the children found it so difficult to accept the reality of life, although they had received education about religion and how they interpreted the meaning of life associated with the realities of life and religious beliefs. The objective of the research is to show the children's inability to accept the reality of life in connection with religious beliefs because the coercive conduct of religion and irrational sermons raises the issue of rationalization of religion that leads to dilution of faith.

\section{Methods}

The materials used in this research are primary and secondary resources. The primary resource is the novel entitled Bless Me, Ultima by Rudolfo A. Anaya. The secondary resource consists of some relevant books and website sources. Primary resources are in the form of sentences and phrases quoted from the novel.

The method used in this research is content analysis and the technique of hermeneutics. Content analysis is used to explore the ideas expressed by the author in the forms of statements, questions, and dialogs of the characters. The method of interpretation used in this research is the techniques of hermeneutics (theory of interpretation).

The materials taken from the novel are in the form of quotes that contain and reflect the issue of coercive conduct in defense of religion, which consists of compulsion to read the prayer, Father Byrnes' sermons considered bizarre, irrational, and frightening, and defending the faith by coercion. In addition, materials include the rationalization of religion and the dilution of faith.

The method of this research is content analysis and the technique of hermeneutics. The concepts used to analyze the results of this research are religious rationalization, religious violence, non-believer, and paganism. The results of the research are some data about the characters' thoughts, feelings, and views of teaching religion and violence in the name of religion. The discussion is the analysis of data uses some of the concepts mentioned above. So, the result and discussion will be the analysis of 
coercive conduct in defense of religion, including the compulsion to read the prayer, defending of faith by force, and sermons considered bizarre, irrational, and frightening. The conclusion of the research is that rationalizing religion leads to dilution of faith. Rationalizing religion is a result of the rational and critical ways of thinking of children. Perhaps Anaya wanted to say to the readers that coercive conduct in religion and scary religious teachings might encourage believers to argue rationally, which might lead adherents to be skeptical. The benefit of this research, hopefully, might provide some knowledge for those who are interested in the field of Literature and Philosophy.

The method of content analysis is to uncover, understand, and grasp the message of literary works. This is done by building a concept associated with the literature. Aspects that are outside the literary aesthetics are explored, internalized, and discussed in detail. Elements that are highlighted in the content analysis include, among others, the problem of moral ethics, things didactic, psychological problems, and philosophical values. The procedures relating to procurement data and determine the unit of analysis. Conclusion and analysis process includes understanding of the symbolic meaning of a literary work. The paradigm of this study is a qualitative approach. The qualitative study was used within the conceptual realm in order to deliver the message that a comprehensive literature includes: the validity of semantics and understanding of the symbolic meaning inherent in context; while reliability is used for adjustment between the results of the review of the research literature that has been formulated [4].

The technique of hermeneutics is the process of interpretation. Language is a medium without borders, which brings something in it-not only understood a culture through language but also everything that is contained in the field of understanding. Hermeneutic interpretation is a theory for understanding the meaning of the text, especially in literature. Modern hermeneutics, as presented by Ricoeur [5], states that language is a container of meanings; when someone reads a text, the intention to understand its contents is through interpretation. A researcher is able to reach the deepest meaning because a researcher has a complete knowledge of the culture, religion, and history, not just knowledge of language, literature, and aesthetics.

According to Ricoeur [5], hermeneutics is the best strategy for interpreting the texts of philosophy and literature. The study design involves the interpretation of deep understanding of figurative languages, such as similes, symbols, and metaphors. Coherence is the understanding of the meaning of the element structure and internal relations to integrate all the elements to get the deepest meaning and analogy is the observation of meaning and values. Results are described through analysis involving certain theories, in this context. First, the text is read very carefully and figurative 
language interpreted. Secondly, the text is interpreted to understand the figurative language that contains the idea of the author in the form of the character of the figures highlighted. Lastly, the text is understood in the form of figurative language to show the main idea and to comprehensively convey the author.

\section{Results}

Coercive conduct in defense religion consists of compulsion to read the prayer, Father Byrnes' sermons considered bizarre, irrational, and frightening, and defending the faith by coercion. In addition, materials include the rationalization of religion and the dilution of faith.

\subsection{Coercive conduct of religion}

Coercive conduct of religion includes a compulsion to read the prayer, Father Byrnes' sermons considered bizarre, irrational, and frightening, and defending the faith by coercion.

Coercive conduct in defense of religion, in this case, belongs to violence in the name of religion. It is a collective violence or mass violence. This violence has become a part of the mass action that has occurred in many places throughout the entire history of human life. In the days of Emperor Nero, Christians received the pursuit and torture that was so great, and in Germany, the Nazis slaughtered millions of Jews. In the case of violence involving religion, the justice is to be achieved is justice according to Revelation, which belongs to a group that demands or violence. Violence by them is an attempt to "defend" Revelation. Violence and religion arise when authorities are questioned. This is because both (religion and violence) are a way to challenge and overthrow the authorities. While one obtains power from violence, the other seizes power through claims about tranquility and eternal peace [6]. The coercion through religion contained in the novel includes religious activities, such as a compulsion to daily reading prayers, sermons delivered by Father Byrnes that were considered unreasonable and frightening, then fights among the kids when defending religion. Dilution of faith happens as a result of skepticism. 


\subsubsection{Compulsion to read prayer}

Theological voluntarism can be defended on the basis of proper consideration to metaethics-that, for example, theological voluntarism provides the best explanation for the impartiality of morals, or for its overridingness, or for its normativity, or for its content. But theological voluntarists have tended to argue that theological voluntarism has something specific to offer to theists. One of these benefits on offer is that theological voluntarism fits well with the centrality of the virtue of obedience in theistic thought and practice. God is a being to be obeyed, is someone who is a practical authority over us.

Feeling forced to carry out religious activities continuously sometimes became a burden to the followers of the religion. Tony, his brothers, and his father felt very depressed because they had to carry out the religious activities recommended by Mary, Tony's mother. Because of that necessity, all family members became bored but were unable to resist. The force of religious activity is reflected in the frequent invocation of Tony's family. As they were bored, they were no longer able to appreciate the essence of the prayer. It was not only the children who felt very bored; even their father had started to get angry at the mother for the constant religious activities. All the family members felt tired and sleepy, then they fell asleep. Tony was trying to please his mother and forced himself to survive, but finally, he fell asleep and dissolved into a dream. Tony's mother hoped that someday her son would become a priest; meanwhile, his brothers demonstrated unfriendly and strange attitudes-they shouted and made Tony scared.

\subsection{Compulsion to read prayer}

"We must pray," 'she beamed with joy although her eyes were red with crying.' 'She lit many candles for the Virgin and she allowed Ultima to burn sweet incense at the foot of the Virgin's statue.' 'Then we prayed' [7].

"We prayed rosary after rosary until the monotonous sound of prayers blended into the blur of flickering altar candles" [7].

"I do not know how long they prayed. I only know that my soul floated with the holiness of prayer into the sky of dreams. I was at the river, and I heard someone calling my name" [7]. 
"'Maria,' my father complained, 'but we have prayed all night!' 'Nevertheless we had to kneel for one more prayer"' [7].

"We prayed until our faith passed into an exhaustion that numbed us to sleep. The first to fall asleep was Theresa, and my father quietly got up and took her to bed. Then Deborah nodded and toppled. And I, who wanted to endure to please my mother, was next. I felt my father's strong arms carrying me out... I do not know how long they prayed. I only know that my soul floated with the holiness of prayer into the sky of dreams" [7].

"'Tony, you goin' be her priest!' 'Bless us, Tony!' They knelt on the ground and raised their arms up and then down towards me. I grew frightened at their wild actions, but I found enough to shout at them" [7].

\subsection{Father byrnes' sermons considered irrational and frightening}

Father Byrnes went on to discuss the difference between mortal and venial sins. His explanation was very simple, and in a way frightful. Venial sins were small sins, like saying bad words or not going to the Stations of the Cross during Lent. If you died with a venial sin on your soul you could not enter heaven until the sin was absolved by prayers of rosaries or masses from your family on earth [7].

The father nodded. "And is there any escape from hell?" he raised his finger. We nodded no in silence. "No!" he shouted and slapped his hands so we all jumped in our seats. "There is no hope in hell! Hell is a place of eternal damnation! The fires of hell burn forever and ever [7].

"But if you die with a mortal sin on your soul you could never enter heaven. Never! It was frightening to think of missing mass on Sunday, then dying, and for that one mortal sin to go to hell forever" [7].

"Now I'm going to tell you a story that will teach you how long eternity lasts. Now, keep in mind, this is how long your soul will be burning in hell if you die with the black spot of mortal sins on it. First, try to imagine our whole country is a mountain of sand. A mountain of sand so high that it reaches to the clouds, and so wide that it stretches from one ocean to the other" [7].

The dead might enter heaven until the sin was absolved by prayers of rosaries or masses from one's family on earth; then when pastor explains the length of time of the dead staying in hell. Pastor Byrnes compared the length of time with the imagination 
of the whole country is a mountain of sand that it reaches to the clouds and stretches from one ocean to the other [7].

"Gee whiz!" Abel's eyes opened wide. Horse, sensing something he could not understand, began to get nervous. Bones rolled his eyes. We all waited patiently for father's story to develop because we knew he had a way of telling stories that very clearly illustrated the point he wanted to make. I thought of Florence holding his arms outstretched for eternity [7].

"Let us pray," Father Byrnes said and knelt. We followed suit, kneeling on the rough, splintery knee board of the pew. Only Florence remained standing, holding the weight of his arms which would become numb like lead before catechism was over [7].

Down the row, I heard Bones faking it. "Buzz, buzz, buzz," his mouth moved to the words, but he didn't know them. His head was bowed, his eyes closed, and he looked so devout that no one could doubt his sincerity [7].

Then the priest quizzed us on some lessons we had already been through: "Who made you?" he asked. "God made me," we answered in unison. "Why did God make you?" he asked, and I saw him look down the aisle at Florence. "God made us love, honor, serve and obey Him" [7].

"Where is God?" "God is everywhere." "At Rosie's," Bones whispered and rolled his eyes. Father Byrnes didn't hear him. "How many persons are there in one God?" he continued. "Three. The Father, the Son, and the Holy Ghost." "The ghost," Bones said secretly, "the holy ghoooooo-st" [7].

"They have to be squeezed in tight," Horse grinned with his ugly horse teeth, and he took the white stuff he had been picking from them and wiped it on his pants [7].

"If you died with a venial sin on your soul you could not enter heaven until the sin was absolved by prayers of rosaries or masses from your family on earth. But if you died with a mortal sin on your soul you could never enter heaven. Never. It was frightening to think of missing mass on Sunday, then dying, and for that one mortal sin to go to hell forever" [7].

"If you die with a venial sin on your soul, where do you go?" he asked. "To Purgatory," Rita answered. The girls always knew the exact answers. I knew 
most of the answers but I never raised my hand, because I often wanted to ask questions and I knew it would displease father if I did. Really, the only one who ever asked any questions was Florence, and today he was doing penance [7].

"That's right, Rita," he smiled. "And what is Purgatory?" Purga," Abel whispered. The boys giggled. "I know! I know!" Agnes waved enthusiastically and father smiled. "It's a place where souls are cleaned so they can go to heaven!" [7].

"And if you die with mortal sin on your soul?" he asked, and his voice was cold. The church seemed to shudder from a blast of wind outside, and when it settled a side door opened and an old lady dressed in black hobbled up the side aisle to the altar of the Virgin. She lighted one of the candles in a red glass and then she knelt to pray. "Hell!" Ida gasped, sucking in her breath [7].

The father nodded. "And is there any escape from hell?" he raised his finger. We nodded no in silence. "No!" he shouted and slapped his hands so we all jumped in our seats. "There is no hope in hell! Hell is a place of eternal damnation! The fires of hell burn forever and ever" "Forever and ever," Agnes said thoughtfully. "Is that how long eternity is?" Agnes asked bravely. "Is that how long the souls have to burn?" "For eternity!" Father Byrnes said emphatically [7].

We gasped and fell back in our seats, shuddering at the thought of spending eternity in hell. The story made a great impression on us. "It would never finish," June shook her head sadly. Horse sat by me. He was carving his initials into the back of the seat in front of us. The horse never prayed all of the stations, he happened to be sitting by. I looked at the wall and saw that today he had picked to sit by the third fall of Christ [7].

Father Byrnes stood at the first station and prayed to the bulto on the wall that showed Christ being sentenced by Pilate. Two high-school altar boys accompanied the priest, one to hold the lighted candle and the other to hold the incense burner.... The incense was thick and sweet. Sometimes it made me sick inside and I felt faint [7].

The irrational and frightening sermons of Father Byrnes were regarded as coercive conduct. The children hoped that Father Byrnes' sermons were soft, peaceful, and full of soothing words, so the children would feel comfortable. Apparently, the sermons were really far from their expectations; there was no theological enlightenment for the congregation. In contrast, the sermons were full of frightening stories and made 
the children feel annoyed, and they even ridiculed the speeches that were considered weird and unreasonable. According to Ron Arias in his "Bless Me, Ultima" in The American Book Review, the book has some funny scenes and one oddly funny character name the "Vitamin Kid," a compulsive runner who appears throughout as some sort of harbinger of unmentioned forebodings. And just as Anaya skillfully uses a naive narrative focus to heighten humor, especially among kids, he also depicts mystery, violence, and terror through innocent eyes [8].

Father Byrnes' sermon continued with morbid stories that made children very shocked because the pastor's explanation was very scary. Father Byrnes continued, saying that if someone was in hell he would not be able to escape forever. Children assumed that Father Byrnes' sermon was bizarre, frightening, and flavored with terrible stories about sin and hell. They were really confused. Strange feelings and fear made the children became skeptical and finally, they mocked the sermons. Father Byrnes' sermon was terrible when he explained about sin, heaven, and hell. The children assumed that his statements did not make any sense when one could enter heaven only with the ritual. He said that if a person died with a mortal sin, then he would not go to heaven. He called for the man with a great sin to go to worship before he died. His sermons were full of frightening events after death. The teaching of religion made the children desperate instead of offering them peace and joy. Stories about how sinners were burned by the fires of hell made the children become hopeless and filled with fear. They considered that Pastor Byrnes' preaching was irrational and they became puzzled. Listening to the priest's sermons that had come to be far-fetched, the children began to consider that the content of the sermon was hard to believe. They began to doubt the story because they thought it did not make any sense.

Feeling bored and reluctant, the children displayed strange and funny attitudes. When done with the story, the priest invited all pilgrims to continue another prayer. This activity was very boring for the children. There was a child who pretended to be very serious following the religious ceremony; actually, he did not understand what the pastor said. They were getting more and more bored because Father Byrnes was always repeating the same questions in every sermon. As the children considered that the sermon of the priest was very irrational and very boring, they began to make jokes and mocked the priest's sermon. There was even a child who said that God is in a place of entertainment when the priest asked where God was. They no longer listened to the sermon, they even joked and heeded the funny behavior from the others just to relieve their boredom. 
Father Byrnes went on to discuss the difference between mortal and venial sins. His explanation was very simple, and in a way frightful. Venial sins were small sins, like saying bad words or not going to the Stations of the Cross during Lent. Instead, there were some girls who believed in pastor's preaching and who always answered the questions correctly.

Actually Tony could answer that question, but he did not do it because he just wanted to ask questions which he believed it could make the priest angry, such as rational questions. The pastor's sermon, instead of giving satisfaction and enlightenment, evidently was a joke for some of the children. The church was supposed to give a sense of peace and coolness; on the contrary, it seemed to be a grim and frightening place. The voice of the priest even no longer provided a sense of comfort and calm. Feelings of fear enveloped the children, especially when an elderly woman dressed in black entered the church, which astonished them. The pastor was talking about hell, which was devastating for the children. Listening to the pastor's explanation, the children felt as if there was no hope to go to a decent place after death. They were paralyzed by fear and became suddenly aghast when the pastor banged his arm as if to dramatize the terrible story. The children were stunned listening to the pastor's stories because of their fear. As they were unable to accept the truth of the story and their attempt to eliminate the fear, they began to rationalize the teachings of the religion. Tony felt uncomfortable staying in the church because of the experience he felt. Influenced by the scent of the incense, he felt queasy as if he would faint.

\title{
3.4. Defending faith by coercion
}

\begin{abstract}
"You'll go to hell, too, Florence!" Horse shouted, "you don't believe in God!" "So what?" Florence Shrugged, "if you don't believe in God then there is no hell to go to." Then Tony asked: "But why do you go to catechism?" I asked him. "I wanna be with you guys. I just don't want to feel left out," he said softly. "Then that would be hell," he nodded. "I think if there is a hell it's just a place where you're left all alone, with nobody around you. Man, when you're alone you don't have to burn, just being by yourself for all of the time would be the worst punishment the old Man could give you" [7].
\end{abstract}

Ernie said emphatically, "Florence needs the practice! He didn't make it because he didn't practice!" "He didn't make it because he doesn't believe!" Agnes taunted. "Why doesn't he believe?" June asked. "Let's find out!" "Make him tell!" They grabbed tall Florence before he could bolt away and made him kneel in front of me [7]. 
"No!" I protested. "Confess him!" they chanted. They held him with his arms pinned behind his back. "What are your sins?" I asked. "I don't have any," Florence said softly. "You do, you bastard!" Ernie shouted and pulled Florence's head back. "You have sinned," Abel agreed. "Everybody has sins!" Agnes shouted. She helped Ernie twist Florence's head back. Florence tried to struggle but he was pinned by Horse and Bones and Abel [7].

I tried to pull their hands away from him to relieve the pain I saw in his face... his face was very close to mine now, and when he shook his head to tell me that he didn't have sins I saw a frightening truth in his eyes. He was telling the truth! He did not believe that he had ever sinned against God! "Oh my God!" I heard myself gasp [7].

"Confess! Confess!" they cried. Then with one powerful heave and groan Florence shook off his tormentors. He was long and sinewy, but because of his mild manner, we had always underestimated his strength. Now the girls and Ernie and even Horse fell him off like flies [7].

"Confess your sins or you'll go to hell!" Rita cried out. She grabbed his blonde hair and helped Ernie and Agnes twist his head [7].

"I have not sinned!" he shouted, looking me square in the eyes, challenging me, the priest. "It is God who has sinned against me!" his voice thundered, and we fell back in horror at the blasphemy he uttered "Florence," I heard June whimper, "don't say that" [7].

I was facing the angry kids and I could see that their hunger for vengeance was directed at me, but I didn't care, I felt relieved. I had stood my ground for what I felt to be right and I was not afraid. I thought that perhaps it was this kind of strength that allowed Florence to say he did not believe in God [7].

They circled around me and advanced on Florence, their eyes flashing with the thought of the punishment they would impose on the non-believer. It was then the fear left me, and I knew what I had to do. I spun around and held out my hands to stop them. "No!" I shouted, "There will be no punishment, there will be no penance! His sins are forgiven!" I turned and made the sign of the cross. "Go in peace, my son," I said to Florence [7].

Florence grinned. "Why? Because it is the truth?" he questioned. "Because you refuse to see the truth, or to accept me because I do not believe your lies! I say God has sinned against me because he took my father and mother from me when I most needed them, and he made my sisters whores-He has punished all of us without just 
cause, Tony," his look pierced me, "He took Narciso! And why? What harm did Narciso ever do?" [7].

"No!" they shouted, "don't let him go free!" "Make him do penance! That's the law!" "Punish him for not believing in God!" "I am the priest!" I shouted back, "and I have absolved him of his sins!" [7].

"We shouldn't listen to him," Agnes had the courage to interrupt Florence, "we'll have to confess what we heard and the priest will be mad." "The priest was right in not passing Florence, because he doesn't believe!" Rita added. "He shouldn't even be here if he is not going to believe in the laws we learn," Lloyd said [7].

"Give him a penance! Make him ask for forgiveness for those terrible things he said about God!" Agnes insisted. They were gathering behind me now, I could feel their presence and their hot, bitter breath. They wanted me to be their leader; they wanted me to punish Florence. "Make his penance hard," Rita leered. "Make him kneel and we'll all beat him," Ernie suggested. "Yeah, beat him!" Bones said wildly. "Stone him!" "Beat him!" "Kill him!" [7].

"You are a bad priest, Tony!" Agnes lashed out at me. "We do not want you for our priest!" Rita followed. "Punish the priest!" they shouted and they engulfed me like a wave. They were upon me, clawing, kicking, tearing off the jackets, defrocking me. I fought back but it was useless. They were too many. They spread me out and held me pinned down to the hard ground. They had torn my shirt off so the sharp pebbles and stickers cut into my back. "Give him the Indian torture!" someone shouted. "Yeah, the Indian torture!" they chanted [7].

They held my arms while Horse jumped on my stomach and methodically began to pound with his fist on my chest. He used his sharp knuckles and aimed each blow directly at my breastbone. I kicked and wiggled and struggled to get free from the incessant beating, but they held me tight and could not throw them off. "No! No!" I shouted, but the raining blows continued. The blows of knuckles coming down again on my breastbone were unbearable, but Horse knew no pity, and there was no pity on the faces of the others [7].

"God!" I cried, "God!" But the jarring blows continued to fall. I jerked my head from side to side and tried to kick or bite, but I could get loose. Finally, I bit 
my lips so I wouldn't cry, but my eyes filled with tears anyway. They were laughing and pointing down at the red welt that raised on my chest where Horse was pounding [7].

Coercion is the intimidation of a victim to compel the individual to do some act against his or her will by use psychological and pressure, physical force, or threats. Coercion included bondage, brute force, command, intimidation, moral compulsion, repression, strong-arm tactics $[9,10]$.

Violent defense of religion can be done by those who are very fanatical about the teaching of religion. Fanaticism in religion might lead people to defend religion by all means. To defend religion and to emphasize fanaticism was sometimes difficult to distinguish. Someone who was a fanatic could force others to carry out religious activities in the form of persuasion, appeals, and violence. The characters in this novel showed coercion against religious teasers for defending religion.

Florence was Tony's best friend, but most of the children were against him because he had always been blasphemous and he seemed not to believe in God. Tony was surprised because Florence had often been to church, not to worship but to gather with friends. For Florence, hell was on earth or the most severe punishment was someone who lived alone, had no friends, and was abandoned. Different views of beliefs became heated debates because neither side ever understood why they were different and why they did not accept that distinction. If any of them had someone who was different from them, then they thought he was not a part of them. They had the view that all people were sinners before the Lord. Tony defended Florence's assertion because he knew well that Florence was facing suffering in his life. Tony could understand that Florence's rejection of religion was because Florence assumed that God did not bless his family and therefore his family suffered. Tony felt very sad to see the condition of Florence. He was attacked by the others simply because he was telling the truth. Tony was convinced that Florence was innocent.

Perhaps Tony wondered how others might judge whether a person was a sinner or not based on a different view of religious beliefs. How could they have to force someone to confess that he was a sinner and that he would certainly be punished by God? This group of brutal children imposed their will and felt that only those who were the most righteous and the holiest would be before the Lord. Maybe Tony thought Florence should be pitied because he was weak and had a life of suffering. Although he had his own view of theological beliefs, Tony felt that they should not torture Florence in such a way. Florence assumed that what he said was a truth based on the fact of what he and his family had experienced. Perhaps Florence assumed that many 
religious sermons were not in harmony with reality, so he believed there were some theological teachings that were full of lies. On the contrary, on the part of the children, the group believed that Florence's word was a sin. So they thought that Florence's statement could influence their view of theological doctrine. They feared that if they were affected, they would be sinful. Therefore, one the kids suggested that children should not be influenced by Florence's critical statement. This group of children really forced their will and tried to get Florence to be persecuted so that he would apologize for all his words about God. Tony also felt the fierceness of these children and he did not escape from their attack because Tony was considered the defender of the blasphemer.

Actually Tony disagreed with the actions of his friends against Florence. This incident implied that children were evil for torturing Florence because he was blaspheming God. On the contrary, it was so easy for a pastor to free him from punishment by making the sign of the cross. Tony represented the power of religious leaders who seemed to represent God in the world. Perhaps Tony represented Anaya who wanted to say that humans were entitled to determine a person was sinful or innocent. Indeed, Tony could understand why Florence made such a statement with a tone of criticism of God's power. Tony seemed very displeased to witness the bad behavior of his friends simply because of differences in beliefs about the concept of God. Tony was just relieved that Florence dared to express his thoughts freely. Tony supported Florence's right attitude; he was satisfied and confident. Florence's attitude was considered as him having the courage to express his view.

Since Tony was considered to defend the blasphemer of God, he got ill treatment from the group of children. They considered Tony to be incited by Florence's mind. The defenders wanted all children to trust the teachings of the priest. Tony refused to budge because he thought Florence was innocent and was justified in holding a different view about his religious outlook. Tony sensed how violent and sadistic that person were offended by the problem of defending theological beliefs. Although they were friends, when they were offended by a matter of faith, it was not impossible they would kill anyone. Although Tony defended the "blasphemer," he was still a believer. He begged God for help when he suffered.

\subsection{Rationalization of religion}

"What's Immm-ack-queue-let Con-sep-Shion?" Abel asked. And Father Byrnes moved to the station where Christ meets his mother. I tried to 
concentrate. I felt sympathy for the Virgin. "Immaculate Conception," Lloyd whispered. "Yeah? "The Virgin Mary-" "But what does it mean?" "Having babies without-" "What?" "A man and a woman, it takes a man and a woman," Florence nodded. But the Virgin! I panicked, the Virgin Mary was the mother of God! The priest had said she was a mother through a miracle [7].

Of course, the dreams that I had during my illness continued to preoccupy me. I could not understand why Narciso, who did good in trying to help Ultima, had lost his life; and why Tenorio, who was evil and had taken a life, was free and unpunished. It didn't seem fair. I thought a great deal about God and why he let such things happen [7].

Perhaps, I thought, God had not seen the murder take place, and that is why He had not punished Tenorio. Perhaps God was too busy in heaven to worry or care about us [7].

Rationality is brought into the decision-making discourse by the process of rationalization, and it has always been a study of how good the decision (or underlying process) has been or should be $[11,12]$. While rationalization defines thinking activity in general; rationality defines its contents (both goals and procedures). Rationality means the selection of alternatives, through a system of values that allows an individual to make decisions, and to make evaluations of potential and actual consequences of behavior or actions.

Rationalization is the explanation of our behavior (and choices, and way of thinking). It is a mental process that is driven by self-awareness, something that lets us think about what we are doing. Rationalization is the act of making sense of what you do or think, and it happens through your own interpretation categories [12]. Rationalization (reasonable/appropriate by the intellect) is a process or a way of making rational actions (actions to rationalize something that may first seem irrational).

Rationalization of religion was influenced by the free-thinking movement and religious discussions of the Enlightenment that emphasized reason as the ultimate basis of truth. Those who believe in this movement rejected the existence of the supernatural. They embraced religion with a foundation based innately in human reason rather than one transmitted through divine revelation [13]. Application of this principle has many different consequences. Sometimes it is likened to Modernism, either in the form of Protestantism (the critical study of the Bible text) or Catholicism (excessive reliance on reason). Some basic teachings are: (1) Reality can be known-or some truths about reality can be known-it depends on observation, experience, and the use of empirical 
methods. (2) The mind is capable of knowing some truths about reality that precedes any experience (but that is not the analytical truth). (3) Mind is the main source of knowledge, and knowledge is essentially a deductive system that can be rationally understood only indirectly related to this sensory experience. (4) The truth is not tested with verification procedures-sensory, but with criteria such as logical consistency.

This novel showed us that he children were rationalizing religion; according to them the religious preaching of Father Byrnes was irrational and illogical. They found it difficult to accept the pastor's story, such as the belief that the birth of Jesus through a miracle, because according to them, it did not make sense. Generally, rationalism is a philosophical approach that emphasizes reason (ratio) as the main source of knowledge, prior to or superior to, and free (apart) from sensory observation. In theology, the application of this principle is to provide additional meanings: the term sometimes refers to the approach of religious belief, where reason replaces faith. In principle, that reason should be given a leading role in the explanation. In connection with this novel, Tony was very confused to see what happened around him and he considered it difficult to understand because it does not make sense. The religious instruction he has received does not correspond to the reality of life. In his view, everything cannot be construed in accordance with common sense and sometimes the truth is contrary to expectation.

\subsection{Dilution of faith}

"But what is sin?" Florence asked me. "It is not doing the will of God"-I ducked my head and gritted my teeth on the fine sand the wind carried. "Is it a sin to do this?" He threw a finger. "Yes," I answered. "Why?" "It's a bad sign-You will be punished." "When?" "When you die," I said. "What if I go to confession?" "Then your sins are forgiven, your soul is clean and you are saved-" "You mean I can go out and sin, do bad things, throw fingers, say bad words, look through the peep-hole into the girls bathroom, do a million bad things and then when I'm about to die I just go to the confession and take communion, and I go to heaven?" [7].

\footnotetext{
"Yes," I answered. There seemed to be so many pitfalls in the questions we asked. I wanted answers to the questions, but would the knowledge of the answers made me share in the original sin of Adam and Eve? [7].
} 
"The Old Man?" I asked, my question intermingled with a feeling of sadness of Florence. "God," he answered. "I thought you didn't believe-" "I don't." "Why?" I asked. [7].

"So I asked myself," he continued, "how can God let this happen to a kid? I never asked to be born. But he gives me birth, a soul, and puts me here to punish me. Why? What did I ever do to Him to deserve this, huh?" [7].

"I don't know," he kicked a rock. "My mother died when I was three, my old man drank himself to death, and," he paused and looked towards the church which already loomed ahead of us. His inquiring, angelic face smiled. "And my sisters are whores, working at Rosie's place-" [7].

For a moment I couldn't answer. The questions Florence had posed were the same questions I wanted answered. Why was the murder of Narciso allowed? Why was evil allowed? "Maybe it's like the priest said," I finally stammered, "maybe God puts obstacles in front of us so that we will have to overcome them. And if we overcome all the hard and bad things, then we will be good Catholics, and earn the right to be with Him in heaven-" [7]

Florence shook his head. "I thought about that," he said, "but the way I figured it, if God is really as smart as the priest says, then he wouldn't have needed any of that testing us to see if we're good Catholics. Look, how do you test a three-year-old kid who doesn't know anything. God is supposed to know everything, all right, then why didn't he make us so that we would always be kind to each other? He could of made it so that it was always summer, and there's always apples in the trees, and the water at the Blue Lake is always clean and warm for swimming-instead He made it so that some of us get polio when we go swimming and we're crippled for life! Is that right?" [7].

"I don't know," I shook my head, and I didn't. "Once everything was all right; in the Garden of Eden there was no sin and man was happy, but we sinned" [7]. "Bullshit we sinned," Florence disagreed, "old Eve sinned! But why should we have to suffer because she broke the rules, huh?" [7].

"But it wasn't just breaking the rules," I countered, I guess because I was still trying to hold on to God. I didn't want to give Him up like Florence had. I did not think I could live without God. "What was it?" he asked. "They wanted to be like Him! Don't you remember the priest saying the apple contained the knowledge that would make them more things, like God they would know 
about good and evil. He punished them because they wanted knowledge -" [7].

Florence smiled. "That still doesn't seem right, does it?" Why should knowledge hurt anyone? We go to school to learn, we even go to catechism to learn-" [7].

The bible defines foith as "being sure of what we hope for and certain if we do not see." Faith is a channel of living trust-an assurance-that stretches from man to God. In other words, it is the object of faith that renders faith faithful. Faith is the assurance that God's promises will never fail, even if sometimes we do not experience their fulfillment in our mortal existence. Faith that serves to protect us in spiritual warfare is not to be confused with mere knowledge. Faith is generally understood to be closely associated with ideas of belief, trust, and reliance $[14,15]$

Toland stated that the use of reason was to purge religion of superstition and also of corrupt clergy, who preyed upon superstition and sought worldly benefits through manipulation of institutional religion [13]. The perception of priestcraft was based on the methods of priestcraft, which were devoted to confounding and confusing the people so as to make them all the more dependent on the guidance of the Church [13].

Back to this novel, sometimes the children thought that the terrible preaching was intended to make the followers be dependent on the priest. The conversation between Tony showed how important the role of a religious leader was to determine whether a person was sinful or not; then the followers of the church absolutely depended on the presence of a priest. Belief in God relates to faith. By definition, faith is not rational and can be said as being the absence of evidence. Teachings of the religion that address human relations might be considered rational; but when religion is associated with a mortality that cannot provide concrete evidence could be considered irrational, especially for those who do not have strong faith. Rationalizations of religion might come about because someone is losing faith. The reason for losing faith may be caused by understanding the teachings of religion based on reason, while faith cannot be discussed

According to John Toland, church dogma is no longer sufficient in and of itself to warrant obedience to Christianity. The individual believer must make sure the tenets of the true religion accord with his own reason for that religion to have any legitimacy or the religion in question cannot be a true one [13].

Paul, in his "Philosophy" [16], stated that the most significant argument against theism is known as "the problem of evil." The problem of evil can be stated in many 
different ways: the logical problem of evil, the empirical problem of evil, and the probabilistic argument from evil. The logical problem of evil, first identified by Epicurus, is perhaps the strongest objection to the existence of God. According to Epicurus, four possibilities exist 1. If God wishes to prevent evil and is not able to do so, then God is feeble. 2. If God is able to get rid of evil but does not want to, then God is malevolent. 3. If God does not wish to get rid of evil and is not able to get rid of evil, the God is malevolent and feeble, and therefore, he is not God. 4. If God wants to get rid of evil and is able to get rid of evil, then why does evil exist in the world, and why has God not gotten rid of it? (282).

St. Thomas Aquinas responded to the logical problem of evil by stating that it is not clear whether or not the absence of evil would make the world a better place, for, without evil, there would be no meaning of kindness, justice, faithfulness, or self-sacrifice. Another argument against the logical problem of evil, known as the "unknown purpose defense," states that since God can never be truly known, humans have limitations when trying to guess God's motivations (283). The empirical problem of evil, created by David Hume, claims that if one were not exposed to prior commitments, such as religious convictions, the experience of evil in the world would lead to one to atheism, and the notion of a God that is good and omnipotent could not exist. The probabilistic argument of evil is the argument that the very existence of evil is proof that there is God (283).

The novel illustrated that Tony wanted to convey a lot of questions related to the religious teachings he learned, but he was worried that his questions could be regarded as a sin. Perhaps Tony wanted to ask questions which had answers requiring a rational and logical explanation. He hesitated because he felt that this question might require a lengthy discussion and could make the pastor angry and make the pastor regard the questions as proving doubt of theological beliefs. Basically, he hesitated. Tony had heard Florence call God the Old Man. Tony felt confused why God is called the Old Man. Now Tony was convinced that Florence did not believe in God, as there were so many indications showing it. Florence also named his father an old man, then God was the same as father, but his father died of drunkenness. The Lord, according to Florence, is not fair, because God Almighty had made his family suffer. Florence's hesitation on the existence of divinity was based on his own life experience. He considered God to be unfair to innocent children. Why did God Almighty not give happiness to innocent people? These two children had the same understanding of the concept of divinity. They rationalized theological beliefs, which made their beliefs fade. The difference between the two of them was that, for Florence, there was doubt about 
the theological beliefs that he presented based on personal experience. Whereas for Tony, this thought arose from the experience of the people and acquaintances he saw. Florence rationally questioned why the difficulties of life could happen to a small child who did not understand the meaning of life. He believed that if there was a God Almighty, why was He not being fair? Tony was increasingly confused by the rational arguments presented by Florence. Indeed, Tony was still trying to convince himself of God's existence, but Florence continued to make critical arguments that made Tony search for the right answer. Moral accountability of human beings to divine power depends upon the accordance of the divine law with reason [13]. Rationalization of religious teachings can be observed from the sermons delivered by Pastor Byrnes that made the children puzzled.

According to the teachings of the priest quoted by Tony, humans should not explore science in depth, because extensive knowledge was merely a human effort to balance God's power. This was considered by Tony to be a mistake, as God's power could not be equaled by man. Florence considered that many religious teachings fooled human beings. Is it true that human beings were not allowed to explore knowledge so that human beings would become intelligent? Finally, coercive conduct and rationalization of religion lead to dilution of faith.

\subsection{Religious faith in local and global perspective}

There are experts who say religion is very beneficial for those who experience individual neuroticism because by embracing religion one can gain peace and happiness. However, when religion approaches those who experience social neuroticism, then religion can threaten human peace. Adherents of any religion believe that with the adoption of religion they can save their lives in the world and in nature after death. Even many followers of religion are more concerned with life after death because they think life after death is eternal. Since life in the world is temporary then they are oriented to the culture of death by preparing for everything to be as good as possible to meet the requirements of life after death. The essence of religious teachings that promote peace between people may lose their substance because of the strong culture of death. Very often human-to-human conflict occurs because of this view. Even those who follow the same religion can kill each other because of the culture of death. Thus, it is not surprising that inter-religious conflicts occur everywhere in the world. Such a condition occurs throughout human history both in Indonesia and in other countries, and this conflict is very threatening to human life all of the time. 
From the formation of the Republic of Indonesia until today, the issue of religious belief has never been completed completely. If there was a period of peace, the condition was only temporary. If there were any chance, the religious conflict would reappear. Conflict can occur between those who embrace the same religion and those who embrace different religions. The fear of death determines the existential destiny of the rivals. The self and the other employ violence to intimidate one another. They do not realize the worth of value of anything outside themselves. The self who seeks recognition from the other does not accept the reality of the other as something independent and different [17].

These conflicts bring many human casualties. The causes of this conflict involve, among others, coercive conduct that includes forcing a group of people who are against another group to be willing to follow their wishes. Not all believers have the same power of belief. Many of them are skeptical, agnostic, or even "non-believers." There is a view that the issue of religious belief is the affair of each individual, therefore why should there be coercion? When this group cannot accept the compulsion and begin to rationalize religion, the diminishing belief is not impossible.

More dreadful religious conflicts occur in other countries and bring some countries into an endless war and murder. Most of these conflicts actually occur among those who share the same beliefs but different sects. In addition, there are also reasons beyond religious beliefs that cause conflict. Political and economic interests can also be packaged as a religious conflict. For those who are very fanatical in embracing theological belief view rationalization as an unacceptable understanding, even with the reason of peace of human life. Not surprisingly, some developed countries, especially Western countries, and some Eastern countries separate religion from the affairs of nation and state.

The local and global perspectives of religion in some societies are essentially the same. Some people assume that religion must be digested with common sense. Therefore, teachings that ignore common sense need to be revisited. The importance of common sense seems to be an educational process from an early age to an adult age, while those who are fanatical cannot accept what has become a dogma. Questioning religious matters is an unacceptable attitude when it comes to life after death. They have received such teachings as a learning process throughout their lives. Those who use common sense in embracing religion may be more concerned with the peaceful lives of their fellow human beings. The opposition of these two views cannot be solved in a short time because these two understandings are a process of learning that takes a long time. 


\section{Conclusion}

The coercive conduct in defense of religion (covered: the compulsion to read the prayer, defense of faith by force, bizarre and frightening sermons) and rationalization of religion

\section{References}

[1] Herrera S: Bless me, ultima dir. by carl franklin. Hisp. 2015; 98: 632-633.

[2] Wilson C: Magical strength in the human heart. Ploughshares. 1987; 4: 190-197.

[3] Testa D: Extensive/intensive dimensionality in anaya's bless me, ultima. Latin Am Lit Rev. 1978; 5: 70-78.

[4] Endraswara S: Method research on literature. Jakarta: Medpress; 2008.

[5] Ricoeur P: Hermeneutics and the human sciences: essays on language, action and interpretation. Cambridge: Cambridge University Press; 1981.

[6] Juergensmeyer M: Terorisme pembela agama. [Terror in the mind of god - the global rise of religious violence]. Yogyakarta: Tarawang Press; 2003.

[7] Anaya RA: Bless me, ultima. California: TQS Publications; 1972.

[8] Arias R: Bless me, ultima. The American Book Review. 1979; 1: 8.

[9] Farlex: Coercion. 2003 [cited 16 April 2017]. Available from: http://legal dictionary.thefreedictionary.com/coercion.

[10] Kuennen TL: Analyzing the impact of coercion on domestic violence victims: how much is too much. Berkeley J Gend Law Justice. 2007; 22: 2.

[11] Minderop: Coercive conduct and rationalization of religion lead to dillution of faith in bless me, ultima by rudolfo a. Anaya. 2017 [ cited 20 March 2017]. Available from: https://www.google.com/search?q=+rationality\%2C+rationalization\&ie=utf8\&oe=utf-8\&client=firefox-b.

[12] Paul R, Elder L: Critical thinking: tools for taking charge of your professional and personal life. London: Pearson Education; 2013.

[13] Curry MF: Intersections online losing faith: rationalizing religion in early modern england. Intersect. 2010; 11: 207-241.

[14] Hank: What is the biblical definition of faith?. 2017 [cited 21 March 2017]. Available from: http://www.equip.org/bible_answers/what-is-the-biblical-definitionof-faith/. 
[15] Lahno B: On the emotional character of trust. Eth Theory Moral Pract. 2001; 4:171189.

[16] Kleiman P: Philosophy: from plato and socrates to ethics and metaphysics, an essenstial primer on the history of thought. Massachussetts: Adams Media An Imprint of Simon \& Schuster; 2013.

[17] Kamal M: The meaning of terrorism: a philosophical inquiry. NCEIS Res Pap. 2008; 1: 1-1. 